CORRIGENDUM

\title{
Viagra and its use in cardiovascular disease
}

\author{
JM Tomlinson \\ Journal of Human Hypertension (1999), 13, pp 593-594
}

In the above commentary the clinical recommendations of the American College of Cardiology and the American Heart Association in their Expert Consensus Document ${ }^{1}$ were quoted. These stated that co-administration of sildenafil with some CNS drugs-fluoxetine, fluvoxamine, carbemazepine, phenytoin and the statins-by a competitive inhibition of its metabolism may prolong the half-life of sildenafil $\left(\right.$ Viagra $\left.^{\circledR}\right)$. The manufacturers of Viagra, Pfizer Ltd, state that the Expert Consensus Document is incorrect on this and that these drugs do not affect the half-life of sildenafil. The only drugs which significantly interfere with the metabolism of sildenafil and prolong its half-life are those 3A4 inhibitors such as erythromycin, ketaconazole, cimetidine and the protease inhibitors.

\section{Reference}

1 ACC/AHA Expert Consensus Document. Use of sildenafil (Viagra) in patients with cardiovascular disease. J Am Coll Cardiol 1999; 33: 273-282. 